\title{
The Ethics of the Living Wage: A Review and Research Agenda
}

\author{
Andrea Werner • Ming Lim
}

Received: 30 July 2014/ Accepted: 31 January 2015 / Published online: 12 February 2015

(C) The Author(s) 2015. This article is published with open access at Springerlink.com

\begin{abstract}
To date, business ethicists, corporate social responsibility scholars as well as management theorists have been slow to provide a comprehensive and critical scrutiny of the Living Wage concept. The aim of this article, therefore, is to conceptualize the living wage (LW) in its philosophical as well as practical dimensions in order to open up the ethical implications of its introduction and implementation by companies. We set out the legal, socioinstitutional and economic contexts for the debates around the LW and review arguments for, and against, it. Key philosophical arguments from the perspectives of sustainability, capability and externality are invoked and discussed in order to demonstrate the issues and challenges involved for companies, state and civil society actors. Relevant examples from the private sector are examined to demonstrate some of the practical issues involved when the LW is introduced by employers. The article also recommends avenues for a research agenda into the LW for business ethicists, CSR and management researchers in contexts such as the UK, where a voluntary, rather than mandatory, approach to the implementation of the LW is adopted.
\end{abstract}

Keywords Living wage - Business ethics - Corporate Social Responsibility · Voluntarism · United Kingdom

\footnotetext{
A. Werner $(\bowtie)$

Middlesex University Business School, The Burroughs,

London NW4 4BT, UK

e-mail: a.werner@mdx.ac.uk

\section{Lim}

School of Management, University of Leicester,

University Road, Leicester LE1 7RH, UK

e-mail: m1170@leicester.ac.uk
}

\section{Introduction}

'More than 5 million people in the U.K. are paid less than the living wage'

- Toby Helm, The Observer, 3rd Nov 2013

Although the U.K. is ranked as the sixth largest economy in the world by nominal GDP (World Bank 2013), there are more than five million people, or about $21 \%$ of the working population (Markit 2013), who struggle to make ends meet in a 'low-wage economy,' with women and young people being disproportionately affected (Helm 2013). This problem is exacerbated by rising living costs, stagnant wages (Whittaker and Hurrell 2013) and the growing retreat of the welfare state, which makes it more difficult for those on low wages to receive supplementary welfare payments from the government (Davis et al. 2014). At the same time, observers note an increase in pay inequality and excesses in remuneration for those at the top of business organizations (IBE 2014).

The headline at the top of our paper comes against the backdrop of a growing debate around the living wage (LW) concept in the UK. Its supporters and detractors hold equally trenchant views about its merits and dangers, respectively. Whilst powerful community groups and other activist organizations such as Citizens UK and the Living Wage Foundation strongly advocate the LW, industry leaders and economic think tanks have been more sceptical-even hostile - to the concept and its implementation (Groom and Kuchler 2012; Shackleton 2012).

At a fundamental level, the concept of the LW has direct implications for business organizations, clearly, as it concerns how much they pay their workers at the bottom of the pay scale. The concept also raises questions about the dignity of individuals and their families as well 
as the rights and obligations of employers to their employees. Furthermore, a tangle of issues related to who, how and why the LW ought to be paid to workers has to be considered in such debates. So far, academic interest in the LW has been mainly pursued by economists (e.g. Pollin 2005; Harcourt 1997; Figart 2004; Ciscel 2000; Stabile 2008), geographers (Wills 2009), sociologists focusing on labour studies (e.g. Luce 2004), social policy scholars (e.g. Bennett 2014; Grover 2008), political scientists (Waltman 2004) and public health scholars (Flint et al. 2014). Only a few articles in business ethics journals make passing references to the LW (Karnes 2009; Bowie 1998; McMahon 1985), particularly in the context of sweatshop labour and supply chains (Arnold and Bowie 2003, 2007; Preiss 2014).

The purpose of this paper, therefore, is to identify and clarify the arguments for the LW, to outline challenges and problems associated with the concept and to set out its implications for businesses. As an equally important contribution, the debate around the LW will be contextualized in the changing social contract between governments, businesses and civil society with the aim of identifying a research agenda for the LW that is both theory- and practice-driven. As we will go on to explain, we believe that the voluntary nature of LW adoption in the UK makes it a richer site for further research than it would be in the US. We have taken the somewhat unusual step of undertaking both a critical literature review and of presenting two illustrative examples of companies that have implemented the LW. In doing this, we hope to generate a reciprocal dialogue between philosophy and practice.

Our paper is structured as follows. We begin by defining and scoping the concept of the LW, noting the differences between national contexts for comparative purposes. This is followed by a historical and philosophical review of the relevant (and foundational) philosophical concepts that underpin the concept. The LW is not an idea that is unique to contemporary industrial and post-industrial societies, even though it came to prominence as a term during the late nineteenth and twentieth centuries (see Figart 2001, Wills 2009). Its roots, as we note in the sections below, go back to medieval thought. Following this section, we consider the arguments of key modern thinkers on the LW who develop key facets of the construct. Specifically, we examine in some detail how the concepts of sustainability, capability and externality are crucially important in developing a better understanding of what is at stake in the debates. In the 'Discussion' section of our paper, we present two short examples-Scottish and Southern Energy (SSE) and Penrose Care-to illustrate the managerial implications of the LW for businesses. Finally, we set out a range of research questions that merit further exploration by business ethics, Corporate Social Responsibility ${ }^{1}$ (CSR) and management scholars.

\section{Definitional and Conceptual Issues}

The LW is not an easy concept to define. An important distinction is to be made between the national minimum wage (NMW) and the LW. The NMW is a legal threshold, defined as the minimum pay per hour to which workers are legally entitled (UK Government 2014). Legal minimum wages, however, are not necessarily living wages, that is, wages that would meet people's needs (Waltman 2004, p. 9). Minimum wages should be understood as a 'wage floor' for unorganized labour (Figart 2004, p. 2), which are, in contexts such as the UK and the US, rather cautiously set so as to ensure affordability for businesses and not to undermine 'economic competitiveness' (Low Pay Commission 2014; Grover 2005).

In contrast to the NMW, the LW relates to people's subsistence and needs and is, therefore, far more controversial and emotive. As Ryan (1912, p. 82) defines it, the $\mathrm{LW}$ is 'the amount of remuneration that is sufficient to maintain decently the labourer.' At the same time, the LW is also a relative concept. According to Stabile (2008, p. 10), 'low wage workers should earn a living wage as defined by the standards of the community in which they live and work.' Some definitions of the LW explicitly refer to a wage level that would make workers (and their families) independent of welfare or other public subsidies (e.g. Ciscel 2000; Muilenburg and Singh 2007). This endeavour remains controversial, however, particularly if the LW concept is tied not just to the worker's individual needs but the needs of his or her family (Bennett 2014). Clary (2009, p. 1065), for instance, has defined the LW as 'a wage equivalent to the poverty line for a family of four, or the amount of income generated by such a wage that would allow such a family to secure the food, shelter, clothing, health care, transportation, and other necessities of living in modern society.'

Some famous treatises about the LW, such as papal encyclicals, have also conceptualized the living wage as a family living wage, and thus emphasized the role of men as breadwinners for their families (see Figart 2001, Ryan 1912). This argument has been criticized by feminists who have viewed this focus on men as breadwinners as being inherently negative towards women in the workplace (Ciscel 2000). In fact, it is often women who work in occupations such as cleaning, catering, childcare, care for the elderly and the sick, and routine office jobs and who are affected by low

\footnotetext{
${ }^{1}$ Corporate Social Responsibility refers broadly to the notion that businesses either need or desire to do social good whilst carrying out their usual (profit-oriented) activities. This construct, like any other, remains contested and controversial among ethicists and business scholars.
} 
pay (Figart 2004, p. 3), and a LW would be particularly important if those women are single parents (Ciscel 2000).

\section{National Differences}

There are differences in how the LW is framed and implemented in different national contexts. In some national contexts, such as France or Australia (Grimshaw 2004; Figart 2004), negotiation for, and implementation of, a living wage happens through long-established and strongly embedded systems of low-wage regulation. These could be either strong minimum wage laws (e.g. an automatic indexation of the minimum wage) or a high level of collective bargaining power or a combination of both (Grimshaw 2004, p. 101).

By contrast, both in the UK and the US, the LW has been promoted by civil society campaigns (see Pollin and Luce 1998; Figart 2004; Wills et al. 2009). These campaigns can be regarded as a response to the legacy of Reaganomics in the US and Thatcherism in the UK, which, in the 1980s, brought about a shift from Keynesianism to neoliberalism: the promotion of private-sector growth and the subsequent decline of an activist state that would protect the needs of the common man or woman (Mutari and Figart 2004; Grover 2005; Jenkins 2007; Nunn 2014). Both countries have minimum wage legislation, but it is considered weak as it has no automatic indexing (Grover 2005; Grimshaw 2004). Reaganomics and Thatcherism have also led to a decline in union density and power (Pollin and Luce 1998; Grimshaw 2004). Perhaps because of this, both the US and the UK have some of the largest proportions of low wage workers in developed economies. ${ }^{2}$

Despite these similarities, however, there are some differences between the two countries. In the US, civil society groups (mainly community-church partnerships) have been targeting local municipalities, campaigning for local LW ordinances. These 'living wage ordinances' are legally binding agreements that require municipalities to pay a $\mathrm{LW}$ to their direct employees. They also require private businesses, who provide services to the municipality or receive local subsidies or tax breaks, to pay their employees at least the (locally determined) LW rate (Buss and Romeo 2006). ${ }^{3}$ For these private contractors, paying a LW to their employees becomes a matter of compliance if they wish to do business with, or otherwise benefit from engaging with the local municipality.

\footnotetext{
$225 \%$ of US and $21 \%$ of UK full-time workers earn less than twothirds of median hourly pay (OECD Labour Market Statistics, cited in Whittaker and Hurrell 2013).

${ }^{3}$ It should be noted that there are some companies operating in the US that have made a public commitment to paying a LW to their workers (see footnote 10). However, companies have not been direct targets of LW campaigns in the US.
}

In contrast, the focus of the LW movement in the UKspearheaded by Citizens UK, a coalition of faith institutions, schools and other civil society actors-is on the voluntary adoption of the LW nation-wide by employers in all sectors. After some initial LW campaign successes in East London in the early 2000s, Citizens of UK established the Living Wage Foundation in 2011, which offers accreditation to all UK employers who are committed to paying at least the LW to their employees and require their subcontractors to do the same for their employees.

A number of LW campaigns in the UK focus on public sector institutions such as local councils (these campaigns are somewhat similar to the US campaigns, as they seek to obtain a binding commitment from these public sector organizations, albeit via a different mechanism, i.e. accreditation.) But other campaigns in the UK also explicitly target private-sector businesses without government contracts, which contrasts with the approach pursued in the US. ${ }^{4}$ As mentioned earlier, this nudging of private-sector companies to engage with the LW concept as part of their moral obligations or their corporate social responsibility provides a richer context for CSR, management and business ethics research compared to those contexts in which paying the $\mathrm{LW}$ is a matter of compliance or adherence to long-established bargaining processes only. It raises a number of questions about motivation for, and implementation of, the LW in private-sector organizations, which CSR scholars are well placed to explore.

We emphasize that even though the UK is used as a primary example in this article, the arguments put forward will be of interest in the national contexts, where LW movements are beginning to follow a similar trajectory of voluntary adoption and accreditation, such as in New Zealand. ${ }^{5}$ It should also be noted that the LW, although enjoying growing acceptance in public discourse in a number of countries, is still only a limited way of addressing problems of rising economic inequality, an increase of long-term low-wage jobs, and a decline of unions and legal protection for workers. The arguments made in this article apply also to developing economies. In fact, in the view of very weak or absent welfare systems and labour regulations, the adoption of a voluntary LW wage, by indigenous businesses and, importantly, multinational corporations in their operations in these countries and in their supply chains, will be of even more significance, although the challenges of implementing a LW will also be greater (see ETI 2014a).

\footnotetext{
${ }^{4}$ http://www.livingwage.org.uk/. Accessed 10 October 2014.

${ }^{5}$ http://www.livingwage.org.nz/. Accessed 10 October 2014.
} 


\section{Historical and Philosophical Context}

As an idea, the LW has, in fact, been presented in the works of ancient Greek philosophers and medieval scholars. Greek Philosophers like Plato and Aristotle grounded their arguments for an income based on needs in the context of the common good, that is, the notion that the acquisition of wealth needed to be moderated by concern for the communal good (Stabile 2008, p. 12). Aristotle emphasized the need of households to take care of themselves and be self-sustaining. He assigned the state (and thereby the more wealthy members of the community) the responsibility to provide the poor with means to earn an income that would enable them to earn a sustainable livelihood (Aristotle 1999, Book 6, Part V). Even though paid employment was not the rule in the ancient Greek city state, Aristotle regarded proper earned income as essential to establishing self-reliance among all members of society (Stabile 2008, p. 15).

In medieval times, the idea of a 'just wage' was built on the notion of a 'just price.' Aquinas (1947 [originally written 1265-1274], II-II, 66) thought it was morally proper for humans to seek material possessions to provide for their sustenance. In a money-based society, Aquinas argued, prices had to be just to ensure that all members of society had access to necessities (ibid., p. 77). Just as a 'just price' was the outcome of a combination of fair bargaining and informed consent, a 'just wage' was the outcome if both employer and employee knowingly and voluntarily agreed to the wage (Waltman 2004, p. 33). A wage rate that pushed workers below a subsistence level eroded their chances of being virtuous and was therefore considered unjust (Stabile 2008, p. 15). Medieval scholars already recognized unequal bargaining positions as a moral problem, especially where wages were involved. St Antonio, for example, considered it unfair and sinful to pay less than the just wage because a worker had mouths to feed (Waltman 2004, p. 33).

A few centuries later, Adam Smith-although considered the first proponent of the 'free market economy' believed in paying all workers at least what we would call today a LW because it would ultimately benefit society in the form of increased productivity, wealth distribution and economic growth (Clary 2009). Scholars are not in agreement, however, as to whether Smith would have favoured state-enforced policies (ibid.) or the free market (as opposed to mercantilist systems that protected the interests of employers) (Stabile 2008, p. 18). To understand the set of key tensions between the hand of the state, on the one hand, and those of private interests and obligations, on the other, we now turn to three more contemporary accounts of the LW.

\section{Three Contemporary Accounts of the Living Wage}

Much of the contemporary literature on the LW is focused upon campaigns in the US (e.g. Pollin and Luce 1998; Reynolds 2001; Luce 2004; Luce 2005; Adams and Neumark 2005a; Snarr 2011). Philosophical/ethical perspectives on the LW are to be found primarily in the works of three scholars from the turn of the twentieth century up to the present day who have, in our view, made extensive and important contributions on the subject-John Ryan (1869-1945), Jerold Waltman (b. 1945) and Donald Stabile (b. 1944). Though their arguments draw on a range of well-known moral philosophical and economic theories and concepts, they may take on new pertinence in the age of neoliberalism, globalization and the weakening of the welfare state.

The key argument Ryan makes, in his seminal work dating from the turn of the nineteenth/twentieth century, is that the claim to a Living Wage is of the nature of a right, to which all labourers are entitled (Ryan 1912, pp. 43 and 46). According to him it is a natural right, derived from each individual's rational nature (ibid.). Drawing on Christian tradition, Ryan argues that every human being has an 'imperishable right to a livelihood from the common bounty of nature,' and that thus the labourer is endowed with an 'absolute right to at least sufficient remuneration to maintain his life' (ibid., p. 27). However, whereas the right to subsist is an original and universal right, the right to a LW is a derived right, as it supposes a wage system as form of industrial organization (ibid., p. 68). The labourer's right to a LW is mirrored in the employer's obligation to pay a LW. This obligation is grounded in the employer's private ownership of resources. Ryan argues that ownership is an appropriation of the resources of nature, which diminishes the amount of resources to others (ibid., p. 100). Thus, the right to ownership comes must be exercised in a way which is consistent with the rights of others (ibid., p. 104). This means that employers (owners) have the responsibility to pay their workers a LW, as wages are their only means through which the workers' right to a decent livelihood can be realized (ibid., pp. 100-101). For Ryan, the obligation to pay a LW is primarily a matter of distributive justice (ibid., p. 122) and not of production, as it is about 'enabling one group of individuals to secure a portion of the national product that is now regularly obtained by other groups' (ibid., p. 321).

Whilst Ryan emphasizes the right to a Living Wage as derived from an individual's intrinsic worth and sacredness (ibid., p. 56), Waltman (2004, p. 13) provides a rather different argument, based on 'civic republicanism,' in his early twenty first century work on the LW. In his book, $A$ Case for the Living Wage (2004), he seeks to defend the $\mathrm{LW}$ in contrast to liberal individualism. Like Aristotle and Plato, he argues that individual citizens must be intimately connected to the community, and that their interests are 
inseparable from those of the community (p. 14). For Waltman, the LW addresses the twin problem of (in-work) poverty and inequality (Waltman 2004, p. 85), both of which he considers inimical to civic republican ideas. With regards to poverty, he argues that each citizen should be autonomous, able to make choices for him- or herself and that a LW can help people reach a threshold of autonomy (p. 17). Material inequality, on the other hand, can destroy the basis for legal and political equality (on which modern societies are built), as vastly different incomes lead to disconnect between the rich and the poor in one society (p. 24). This may lead to skewed political participation (p. 25) and impair public institutions-as private options for the rich may, for example, affect the quality of public transport and schools (p. 25). Waltman, in particular, criticizes the exaggerated protection of property rights in liberal individualist thought (p. 12), in comparison to other rights that all citizens should enjoy.

Last but not least, Stabile (2008) offers arguments for the LW from a moral economy perspective. He contextualizes the debate around the LW in the tension between the (neoclassical) market economy and the moral or the social economy (Stabile 2008; Figart 2001, 2004). In market economic thinking, wages are 'a market estimation of what a worker adds to the production of goods and services that society wants' (Stabile 2008, p. 2). Thus, low wages mean low productivity, and if more were paid to these workers, that means, that income is transferred from someone else. Furthermore, the market system rests on a structure of incentives, and paying workers a LW may tamper with this incentive structure (ibid.). For these assumptions to work, market economists rely on the model of perfect competition (ibid., p. 10), which places workers and employers in equal positions in a bargaining situation-an unrealistic model in a world where usually employers enjoy more power than workers, especially in the (not-unionized) low wage sector (Stabile 2008, p. 56). This concept of unlimited bargaining, with the presumption of equal power between the two parties as the basis for wage justice, has also been fiercely criticized by Ryan (1912, pp. 4-5, 35). Referring to the notion of productivity, Ryan argues that 'on account of ignorance, immobility, or failure to assert themselves' a number of workers 'are paid much less than the value of the group's marginal product' and that wages also 'tend to equal that of its least productive members' (ibid., pp. 231-232). Thus, wages are not tightly linked to the productivity of the worker, which is also true for the top-end of the income scale, where high executive remuneration does not necessarily mirror high productivity (Perel 2003).

In his review of moral economic thought, Stabile highlights three themes-sustainability, capability, externality-around which he constructs his arguments for the
LW. These three themes feature to a larger or lesser extent in the writings of all three authors, and they provide the structure for the following sections, in which arguments for, and challenges of, the LW concept will be outlined.

\section{Sustainability}

The first argument is, at a basic level, about workers being paid a wage that enables them to sustain themselves (Stabile 2008, p. 4). Ryan regards the ability to earn a decent livelihood as a right and duty, which is grounded in the intrinsic dignity and worth of the person (1912, pp. 74, 32-33). Stabile (2008), on the other hand, grounds his arguments for sustainability in a more systemic, social utility view: if, because of low wages, workers were forced to work long hours, this would diminish their strength and longevity, and lead to a depletion of resources (Stabile 2008, p. 4). He contends that thinkers such as Smith, Bentham, Mill and Marx were particularly worried over the sustainability of the workforce (ibid., p. 55). It is interesting to note that these very early concerns still affect a number of workers today. Immigrant workers in particular may have to hold down several jobs to make ends meet (Wills 2009), and this would, inevitably, affect their productivity and efficiency.

A contemporary extension for using sustainability as an argument for the LW relates to 'social sustainability.' Even though concerns over growing inequalities in income and wealth could be framed as a pure social justice problem, the 'social sustainability' argument would say that economic inequalities within one society erode social cohesion and trust (Bijl 2011; Waltman 2004), which in turn may pose challenges for businesses that operate in such societies. This was shown, for example, in the 2011 England riots, when thousands, mostly young, people from 'disadvantaged' communities in London and other English towns and cities took to the streets and looted, and set fire to, local retail parks and shops. An equally fierce albeit less violent protest has been the Occupy Movement, in which people in the US, the UK and several other countries protested in 2011 against growing inequality and wealth disparity between the top $1 \%$ and the rest of the population. The LW may be a small, yet an important, contribution to social cohesion and sustainability.

Stabile points out that wages enabling the workers to sustain themselves are about more than food: they are also about those necessities that enable a worker to participate in society (Stabile 2008, p. 55 citing Seligman 1968). These necessities may include having enough money for decent accommodation, transport, clothing and personal care (Ciscel 2000). These requirements may change over time and are subject to cultural norms and macroeconomic circumstances (Stabile 2008, p. 54; Waltman 2004, p. 21; Ryan 1912, pp. 126-127; Figart 2001). Subsistence wages 
may thus be considered in the context of 'relative poverty,' that is, what goods can be purchased from a low wage, relative to the goods that can be acquired by the wealthy in society (cited in Stabile 2008, p. 26 citing Marx 1977 [originally written 1867]). This gives rise to discussion and debate as to what 'subsistence' needs should include.

\section{Capability}

Related to, and an extension of, the sustainability argument is that a LW should enable workers to enhance their capability (Stabile 2008, p. 5). All three writers touch on this argument in their writings. Ryan (1912, p. 73), in what could be regarded an early conceptualization of the concept, argued that in addition to having food, clothing and shelter, humans must have 'opportunity to develop within reasonable limits all [their] faculties, physical, intellectual, moral and spiritual.' According to Ryan, a decent livelihood coming from a proper wage is essential to meet the 'minimum conditions of right and reasonable living, since without them [humans] cannot attain to that exercise of his faculties and that development of [their] personality that makes [their] life worthy of a human being.'

Waltman (2004, p. 19) and Stabile (2008, p. 5) explicitly refer to Amartya Sen's work on capabilities. Sen (1999, pp. 73) distinguishes between functionings, capabilities and commodities. Functionings refer to the various 'doings or beings' that a person achieves. 'Capability' refers to the alternative combinations of functionings that are reasonable for a person to achieve. In other words, whilst the combination of a person's functionings reflects her actual achievements, her capability set represents her freedom to achieve the functionings she has reason to value. Sen holds an open-ended, pluralist conception of functionings and capabilities (ibid., pp. 75-76; Robeyns 2005). He argues that income is an important means to capabilities, though not the only one (ibid., p. 90). In Sen's framework, commodities are seen to be relative to the context in which a person finds herself (ibid.). Thus, even relative deprivation in income (for example, a relatively poor person in a rich country) can lead to absolute deprivation in terms of capabilities as more income is needed to buy enough commodities to achieve the same functionings (ibid., p. 89, our emphasis).

Building on Sen's arguments, Waltman (2004, p. 19) emphasizes that a certain level of economic well-being enhances people's freedom and autonomy as citizens. Stabile (2008, p. 96), on the other hand, refers more explicitly to people's capabilities in regard to the functions they have as members of society and as workers, and to their ability to enhance capabilities in their children. He thus refers to a more 'instrumental' view of capabilities, beyond their relevance to the well-being and freedom of individuals (see Sen 1999, p. 296).
It is inarguable that higher incomes enable people to have better access to higher quality goods (e.g. food) and to goods that enable them to participate in society (e.g. access to the internet) (Stabile 2008, p. 6); things they may have reason to value. Furthermore, because workers on a higher wage can afford to work fewer hours to make ends meet, they would also have more time available to spend with their families, to attend evening classes or to get involved in their communities.

Work itself may be considered as aiding the development of people's capabilities. Waltman (2004) sets out various personal and social dimensions of work, which are related to capability. ${ }^{6}$ He points to the problem that people in low-paid jobs may feel 'worth-less' and are thus deprived of the selfrespect that they should normally gain from their employment; but a LW could contribute to changing the way they look at themselves and their work (see pp. 3 and 87). At the same time, Stabile (2008, p. 6) points out that the notion of capability also entails the idea that one should not just look at wage levels but also at working conditions - including number of total work hours (Waltman 2004, p. 193)-and whether they diminish people's capability, or whether they actively contribute to people's development of their capabilities (see Garriga 2014).

\section{Externality}

The final argument that Stabile puts forward relates to externality. It is concerned with the fact that low wages impose cost on others (Stabile 2008, p. 7). Back in the nineteenth century, Sidney and Beatrice Webb called employers who paid below-subsistence wages to their workers 'social parasites.' These employers would impose costs on society, as, by exploiting and exhausting their workforce, they would deplete the nation's capital stock of character, intelligence and energy and also negatively affect reproductive abilities. In this way the 'entire nation would, generation by generation, steadily degrade in character and industrial efficiency' (Webb and Webb 1897/1965, pp. 749-754). Looking at externalities in the economic system, Ryan (1912, p. 311) considers that below-subsistence wages would allow incompetent employers to continue to exist rather than favour competent employers. Stabile (2008, p. 7) adds that because business organizations do not pay the full cost of the 'resource' they are using, they will produce too much of their product due to their lower costs and thus resources are being used inefficiently.

\footnotetext{
${ }^{6}$ Waltman (2004, pp. 86) argues that work provides a structure to life, gives most people a sense of accomplishment, provides a sense of identity, forces us to confront the social world, and contributes to the development and maintenance of a healthy civic life.
} 
In contemporary settings, such as in the UK, low wages pose a cost to society as they are supplemented by meanstested welfare payments such as housing benefit or free school meals, so that people's needs are met. In effect, this means that tax payers subsidize employers (Muilenburg and Singh 2007), who can then carry on using workers as a low-cost resource. This argument carries particularly strong force in contexts where public sector organizations contract services out to private businesses, as these businesses should not benefit twice from tax payers' money (first, by winning a contract that is paid for by tax money, and second, by the tax payer subsidizing labour costs) (Figart 2004, p. 3). But the externality arguments hold for all employers who do not pay a LW.

\section{Challenges Arising from the Sustainability, Capability and Externality Arguments}

The above arguments place the call for a LW on firm theoretical foundations. However, a number of practical and philosophical challenges remain, if one seeks to make the LW a concept that will be effective in the real world. In this section we will consider these challenges in turn.

\section{Sustainability}

With regards to the sustainability argument, the very fact that the LW is a relatively 'loose' concept (Stabile 2008, p. 143), and depends on cultural norms and customs, poses challenges for practical implementations of the LW so that it meets the actual needs of each worker. As stated earlier, this is made even more complicated by the debate, whether the LW should be based on the needs of an individual or a family (Stabile 2008, p. 144), and whether welfare payments to which certain households are entitled should be considered in determining a LW rate (Grover 2008; Bennett 2014, see also footnote 14). Clearly, the needs and circumstances of each individual are different at different points in time; and it would be impractical to demand from employers to pay different $\mathrm{LW}$ rates to each employee according to their needs, if they are doing essentially the same work.

In the literature we find three approaches of 'calculating' the LW, all of which have their own challenges. First, there is an expectation that workers negotiate a LW themselves with their employers (Stabile 2008). This approach can be found, for example, in the guidance provided by the Ethical Trading Initiative for supply chains in developing economies (ETI 2013). This approach may be considered a challenge in environments where organized labour is discouraged and workers are not equipped to engage with the concept of the LW.

Secondly, a LW may be determined using a 'relative' benchmark. This approach has been discussed by the US- based Economic Policy Institute (Bernstein et al. 2000, cited in Ciscel 2004) and by Waltman (2004). Suggested relative benchmarks include a percentage of median earnings or a multiple percentage of the poverty threshold. ${ }^{7}$ Waltman (2004), rather radically, proposes that the LW rate be set as a national standard using a percentage of the earnings that fulltime workers in high income brackets enjoy, whether salaries of certain public officials (p. 122) or whether those in the top $5 \%$ income bracket (p. 123). Whilst Waltman's proposal is not (currently) applied in the real world, his approach is interesting, as it considers the LW relative to the incomes and living standards of the 'wealthy' in a particular society, and thus draws attention to potential excessive inequalities. At the same time, even though a relative LW may be relatively easy to compute, it is more de-coupled from the actual needs of workers and their families (Ciscel 2004).

Last but not least, the LW rate is calculated with reference to an 'absolute' benchmark, that is, the use of a basket of essential goods and services that a household needs to ensure a basic standard of living (Ciscel 2004), taking into account regional variations regarding the cost of these needs. This approach has especially been utilized in US and UK campaigns. US campaigns have used, for example, the Economic Policy Institute's research on family budgets and self-sufficiency standards (Ciscel 2004). ${ }^{8}$ The UK campaign uses the 'basic living costs' calculations by the Greater London Authority for the London LW, and Loughborough University's Minimum Income Standard for the LW outside London (Lawton and Pennycook 2013).

With regards to the use of 'absolute' standards, the challenges are as follows. In the US, an 'ideal' household with one full-time earner and 2-3 dependents ${ }^{9}$ has been used as a benchmark for the promotion of regional LW rates (Mutari and Figart 2004). ${ }^{10}$ At the same time, these calculated rates were not the ones that were finally negotiated and implemented in LW ordinances. Ciscel (2004) states that, in the early 2000s, even though the calculated LW rates for a family of a single earner and two children were somewhere between \$15-16 per hour, the actual obtained rates were

\footnotetext{
7 The poverty threshold in the U.S. is not regarded as being sufficient to ensure an adequate standard of living (see Ciscel 2004).

${ }^{8}$ Ciscel (2004) provides an overview of the differences and commonalities of the different budget calculations done in the US, and some of the challenges involved in calculating these budgets.

${ }^{9}$ Luce (2004) states that in early campaigns the more 'traditional' model of one adult full-time worker supporting another adult and two children was used, as this model is also used to determine poverty thresholds in the US, whilst in more recent campaigns the model of a single adult supporting two children featured more heavily (Ciscel 2004).

${ }^{10}$ By contrast, IKEA, who pays voluntarily a LW in the US, calculates its regional LW rates based on the needs of a single worker without children. That is, its LW rates are the lowest possible, although still higher than the NMW (Clark 2014).
} 
between \$7-12 per hour (which was still higher than the NMW). Luce (2004), however, suggests that over the years adopted LW rates have come closer to calculated rates.

In the UK, on the other hand, the two existing LW rates are calculated as an 'average' of subsistence needs of a selected number of different household types. Thus they are going beyond the use of one 'ideal' household type. These rates are then promoted as the LW hourly rate that employers should adopt (at the time of writing $£ 9.15$ in London, and $£ 7.85$ in the rest of the UK). This approach has a number of critics, who argue that this average rate may not be sufficient for each circumstances individuals or families find themselves in (e.g. Grover 2008, Bennett 2012, 2014). Those academics who calculate the UK LW rate outside London defend their approach, however, by pointing out that, under certain conditions - namely, if both adults work full time in a household of a couple with two children-their calculated rate covers nearly $90 \%$ of all households, and that their approach enjoys legitimacy among stakeholders (Hirsch 2010).

It thus appears that both in the UK and the US, there is a trade-off between a pragmatic approach for making a difference in the lives of working people (for example, the UK LW rates of are significantly higher than the current NMW rate of $£ 6.50$ an hour), and the quest for, or implementation of, an 'ideal' LW. It may not be possible to determine one single LW rate that is 'realistic' and that covers the needs of all household types, in all probability.

It should be noted that hourly LW rates usually presume that the worker is in full-time employment. As such, the LW movement does not explicitly tackle the problem that people may be underemployed, that is, that they would like to work more hours than is offered to them, or that they are on so-called 'zero-hours' contracts which do not guarantee any fixed amount of work and income (Pennycook 2013).

\section{Capability}

The case for the LW helping to enhance people's capabilities is convincing and inspiring, but according to Stabile (2008, p. 97), it still poses a number of issues, for instance: will workers spend their money in ways that truly enhance their capabilities? Also, especially if one holds Stabile's view that capabilities also relate to people's functions as members of societies and workers, would one have a right to tell people how they should spend their money?

Another issue relates to the fact that in a number of national contexts (including the UK and US) LWs are won by the effort of others (i.e. community campaigns) (Freeman 2005), and not (primarily) through the workers' own efforts. Stabile (2008, p. 96) argues that for the development of people's capabilities, it will be more effective if they fight for living wages through organized labour, such as trade unions, since the latter were originally set up to empower workers and help them develop a sense about their own moral character (Stabile 2008, p. 96). He asks if others fight for workers' living wages, will this have the desired effect on their capability (ibid, p. 97)? This challenge is being addressed by LW movements as they involve low-paid workers in their campaigns whenever they can (Wills et al. 2009; Fine 2005), and as they also often work with unions in their campaigns (Grimshaw 2004). At their best, LW campaigns can be seen as 'community unionism' (Fine 2005).

A further challenge related to the capability argument is that if the view is taken that working conditions are also important for people's capabilities, could a campaign for, and the adoption of, an hourly LW rate be too narrow? Which other working conditions should campaigners and employers be focusing on to ensure that workers' capabilities are enhanced?

\section{Externality}

The externality argument requires one to consider explicitly the role of the state/government in their role to ensure that all their citizens enjoy a level of income that enables them to make ends meet. More radical suggestions in this area have included the idea of granting every citizen a basic income, no matter whether they work or not (e.g. van Parijs 1992; Caputo 2008). ${ }^{11}$ More commonly, however, the discussion focuses on the responsibility of governments to supplement wages if they are not high enough for people to care for themselves and their families (Grover 2008, Bennett 2012, 2014; Ciscel 2000). Grover (2005), for example, refers to UK Labour's 'making work pay' policies in the 1990/2000s, which provided generous tax credits and supplementary welfare payments for low-wage employees. Ciscel (2000), on the other hand, argues for social subsidies that are not means-tested and are available for all families, as part of the social contract that work-based societies have with their families.

Some observers, however, are critical of calls demanding that governments address the problem of low pay and in-work poverty solely through the payment of benefits, rather than through seeking to increase incomes through higher wages, particularly in view of past experiences of negative effects on the economy and society. ${ }^{12}$ Grimshaw

\footnotetext{
11 It is outside the remit of this article to review the merits and problems of the basic income concept. Waltman (2004) provides a review of basic income guarantee and similar approaches in his book. 12 Grimshaw (2004), for example, refers to the Speenhamland Laws (1795-1834), under which employers could obtain workers at any wage, since a government subsidy brought workers' income up to scale. As a result, workers had no incentive to work hard or to bargain for higher pay, as income was the same whatever the level of pay (given that most employers paid less than the scale). And workers paid above the subsidy scale found their pay driven down in competition with subsidized workers.
} 
(2004, p. 116) argues that today's wage subsidies such as tax credits, housing benefit and others reject the duty of employers to pay for the social costs of maintaining their workforce and thereby intensify pressures towards 'commodification' of work. He adds that benefits potentially reduce the bargaining power of labour. Also, in times when governments seek to reduce huge public deficits, as currently the case in the UK, higher wages would actually enable the government to save on welfare payments that supplement work income (Grimshaw 2004, pp. 115-116; Waltman 2004, p. 89). Furthermore, universal, non-meanstested benefits, are also less likely to occur, and more likely to be reduced, under such conditions. ${ }^{13}$ Waltman (2004, p. 164) posits that work should be the centre of any welfare reform (p. 164), especially in view of the fact that a life without having to depend on the help of others enhances people's autonomy (p. 18) and in view of the personal and social dimensions of work. ${ }^{14}$

If it is accepted that employers, as the providers of work, have a responsibility to pay at least a LW to their workers the question arises as to what 'internalization mechanisms' should be adopted: regulation (mandatory approach), voluntarism or government incentives (Stabile 2008, pp. 7-8).

\section{Mandatory versus voluntary participation by employers}

A number of advocates of the LW, e.g. Waltman (2004) and Ryan (1912), favour a mandatory approach, that is, that governments make the LW the legal minimum that employers have to pay. Waltman (2004, p. 38) argues that such approach would create a level playing field among businesses and that it would be collectively in the interest of business as higher wages would increase overall purchasing power (ibid., p. 136). Such approach would be supported by Keynesian/post-Keynesian economics, which focuses on improving the demand side to stimulate the economy (Keynes 1936). Keynesian economists make a strong case for wage-led economic recoveries (Onaran and Galanis 2012), in which ensuring that people are paid at least a LW could play an important part.

\footnotetext{
13 Another argument that is important here is that migrant workers, a group disproportionately affected by low pay, also have less access to the welfare system (Bennett 2012).

${ }^{14}$ It should be noted that the current LW rate in the UK falls somewhat short of the ideal of making people independent of supplementary welfare payments. Entitlements such as housing benefits and tax credits are included in the calculation of the rate, otherwise the rate would need to be much higher. So the LW tips the balance of responsibility for basic living standards further away from state support and towards wages but it does not completely free people from 'dependence' on the state (Lawton and Pennycook 2013). It also means that the LW rate is susceptible to change if government policies on welfare change. Grover (2008) therefore suggests the UK approach should be called 'living income' instead of 'living wage'.
}

A mandatory approach is pursued, for example, in USbased campaigns for municipal LW ordinances (albeit at local level with only a limited number of employers affected), in recent campaigns in the US that seeks a drastic increase in the NMW (Eskow 2014) or in countries that have strong NMW regulations. However, opponents of the LW warn of adverse unintended consequences if the LW was to be made mandatory, especially if the current NMW is low. They warn, for example, of increases in unemployment, price increases and fewer entry level jobs ('labour substitution effects') (see Pollin 2005). ${ }^{15}$

Pollin (2005) reports, however, that according to his analysis of a number of LW municipalities in the US, possible negative unintended consequences such as layoffs, price increases and labour substitution were not found to be of significant magnitude. Another US-based study not only confirms that in LW ordinances poverty was reduced but also states that this was at the cost of some disemployment (Adams and Neumark 2005b). At the same time, in the UK, think tanks, who are supportive of the LW, are hesitant to promote a mandatory approach (Lawton and Pennycook 2013). According to their calculations-which presume a 'worst case scenario' - a mandatory implementation of the LW in the UK would reduce aggregate labour demand by 160,000 , and a fall in demand for young employees with intermediate or no qualifications by 300,000 . These, they argue, are high enough numbers to urge caution about a statutory LW. Even if in the long-term it may be desirable to have the LW as a mandatory minimum wage (Waltman 2004), something that would also make economic sense from a post-Keynesian perspective (Onaran and Galanis 2012), there are transitional costs to the economy and society to consider, and the ethical issue arises whether this will be a price worth paying.

By contrast, the UK campaign favours a voluntary, accreditation-based approach, although this approach may be actively promoted by government (Living Wage Commission 2014). ${ }^{16}$ A voluntary approach may avoid a number of above listed unintended consequences, as the LW will be implemented more gradually. This more gradual implementation, on the other hand, limits the positive effect for low-wage workers in the economy overall, as only those who work for accredited LW employers will

\footnotetext{
15 Waltman (2004) adds job shortages during recessions, a large number of business failures among smaller firms, inflation and an increase in illegal workers (undocumented immigrants) to this list. $\mathrm{He}$ provides convincing arguments and evidence that refute the first three objections (pp. 127-148).

16 The preference for a voluntary approach is also in line with the norms and idiosyncrasies of UK business culture more generally. For example, in the UK, a mandatory quota of women on company boards is rejected, whilst at the same time it is considered good practice for companies to try and increase the number of women on company boards as a voluntary measure (Sweet 2014).
} 
benefit from a higher rate of pay. It poses challenges as to how governments and other societal stakeholders can encourage employers to adopt the LW.

Whether a mandatory or voluntary approach is pursued, the main obstacle for the adoption of a LW from a business perspective is that higher wages carry risks (Muilenburg and Singh 2007; Waltman 2004; Pollin 2005). Firms may find it difficult to pay a LW if they cannot absorb these additional costs from their profits or through higher prices, although a number of businesses will be able to do so (Pollin 2005). In contexts where a voluntary approach is encouraged, firms may also find themselves at a competitive disadvantage if they adopt the LW but their rivals do not. There are also difficulties involved in rewarding employees at the higher end of the pay scale if employers have to spend more money on those at the bottom end. Pay differentials may be eroded as a result, and this may be regarded as being unfair.

Countering the argument that higher wages pose additional costs to businesses they cannot bear, Waltman (2004, p. 133) and Pollin (2005) refer to efficiency and productivity gains that businesses may enjoy, for example, through reduced absenteeism and turnover and a subsequent reduction in recruitment, training and supervision costs, as well as a better motivated, and thus more productive, workforce. Paying higher wages would also 'force' employers to think about how their resources, both labour and non-labour, could be more efficiently employed (e.g. through investment in better equipment). In contexts where a voluntary adoption of the LW by employers is encouraged, LW employers may also enjoy reputational benefits (and those employers who do not pay a LW may face negative reputational consequences). In such contexts, the responsibility of customers and other stakeholders to recognize, and 'reward,' LW employers, and shun those who do not pay a LW, will become more pertinent (see Ryan 1912, p. 264).

Considering the challenges of a voluntary approach to paying the LW, the third 'internalization' mechanism, incentives, may be considered a suitable complementary 'strategy' driving the adoption of the LW forward. In the UK, politicians have begun to look into offering tax rebates to those employers paying the LW (BBC 2013), even though these proposals are met with some scepticism by others, particularly in view of practical difficulties of implementing these tax incentives (Lawton and Pennycook 2013). Another interesting proposal comes from pro-LW think tanks, who recommend that government should require stock-market listed corporations to report how many employees they pay less than the LW rate, through new provisions in the 'soft-law' UK Corporate Governance Code (ibid.). Also note-worthy is that incentive structures between employers themselves are beginning to emerge.
For example, Unity Trust Bank, a LW-accredited community bank, has been offering discounts on lending rates for other LW employers. ${ }^{17}$ And some LW-accredited companies have begun to make the $\mathrm{LW}$ a requirement for their suppliers (e.g. SSE, see next section).

\section{Discussion and Implications}

So far, we have set out the range of theoretical arguments to be made both for, and against, the LW. These relate to sustainability, capability and externality. Sustainability and capability arguments call for a wage level that enables a worker to sustain him/herself (and their families) from his/ her efforts expended in work, and that enhances employees' capabilities as human beings, citizens and workers. Challenges related to these arguments include the debate around the appropriate calculation of the LW rate, the question whether more money for workers will indeed enhance their capabilities and whether the call for a LW should not only be about an hourly figure but also about 'capability enhancing' working conditions more generally. Externality, on the other hand, makes the case for the LW by pointing to the costs that employers' use of low-waged labour impose on others, especially the state. Challenges to the externality argument include the quest for the best 'internalization mechanism' and also the cost that 'internalization' imposes on businesses.

In what follows, we lay out explicitly how businesses may engage constructively with these debates, in the context of the voluntary, accreditation-based approach pursued in the UK, and what the implications are. As a practical basis for our discussion, we focus on two accredited LW employers from the private sector, SSE and Penrose Care, as examples of how the LW may be engaged with and incorporated within an organization's structure, ethos and brand.

Scottish and Southern Energy (SSE) is one of the six large energy providers in the UK and a FTSE100 company, headquartered in Perth, Scotland, with operations across the United Kingdom and Ireland. ${ }^{18}$ SSE became an accredited LW employer in September 2013, and is one among the dozen or more FTSE100 companies that are LW accredited. SSE's commitment covers a whole range of direct employees, from sales staff, to metre readers, to office workers. SSE states that the company became a LW employer 'because it believes it is a matter of basic fairness that people should get a wage that is enough to cover their living expenses and SSE believes in being a fair employer.' Some observers have also drawn a link between the

\footnotetext{
${ }^{17}$ http://www.unity.co.uk/offer. Accessed 9 June 2014.

$18 \mathrm{http}: / / \mathrm{sse} . \mathrm{com} /$. Accessed 10 October 2014.
} 
criticisms SSE faced over the over-generous pay of their senior executives a few months before their accreditation and its decision to become an accredited LW employer (Williams 2013).

Penrose Care is a small private care company based in London. ${ }^{19}$ Care providers as a whole do not enjoy a good reputation in the UK, including the treatment of their staff (Triggle 2013; Learner 2013). According to Penrose Care's website, the founders started the company as a response 'to the need to fundamentally reform the home care sector in the UK to help improve elderly care and disabilities care in the UK.' The company's managing director further states that a 'LW for care workers means that those special individuals that have a vocation to care can pursue care as a profession - being able to live securely so that they in turn can help the elderly and disabled in our society feel secure.' The company became LW accredited in Autumn 2012 and is only one of four out of about 1,000 care agencies in London that pay the Living Wage (Homecare 2013).

With regards to the debates around sustainability and capability, the following things should be noted. First, criticism around how the UK LW rate is calculated does not appear to be an issue for the two companies, as well as for the other more than (to date) 1000 UK employers who have adopted the LW. It may, however, remain an issue, and an excuse, for non-adopters. ${ }^{20}$

Second, both companies are aware of the benefits the LW makes to their employees' lives. Both of them post videos on the web, ${ }^{21}$ in which employees speak about how their 'quality of life' has improved since they have been paid the LW. These employees talk about how the LW helps them to meet the cost of the 'essentials of life' such as bills, food, rent and transport; to prevent them from being in debt and to enjoy a better social life. These accounts reflect a plurality of what people value as individuals, and they show to their employers and others that a LW does make a difference and helps employees live better lives and enjoy more freedom.

Furthermore, particularly Penrose Care considers paying at least the LW as just one aspect of creating good working condition for their staff as they seek to 'respect [their] staff for the important work they do,' including paying for staff's travel time (which is not common practice in the

\footnotetext{
19 http://www.penrosecare.co.uk/. Accessed 10 October 2014.

${ }^{20}$ For example, in 2013, the chairman of Arsenal football club refused to adopt the LW because even though he considered the campaign well intentioned, for him the issue was "complex and political'. (Dower and Reidy 2013).

21 Penrose Care: http://www.youtube.com/watch?v=jIM_ptAhFQw. Accessed 10 October 2014. SSE: http://sse.com/newsandviews/allar ticles/2013/11/making-a-difference-to-sse-employees/. Accessed 10 October 2014
}

care sector) and offering of training and continued professional development opportunities; all of which are likely to be conducive to the development of their employees' capabilities.

The biggest problem that businesses wishing to implement the LW face, however, is related to the externality argument. It is about the costs that being a LW employer brings to an organization. For some businesses, this may raise questions of viability, whilst for other business organizations the challenge will lie in explaining to their shareholders why they intend to spend more money than legally required on their staff. Without any doubt, companies that employ a large proportion of low-waged workers (such as large retail chains) or that are constrained in their resources (especially smaller firms) will find it less easy to become LW employers than those in which only a small fraction of staff is affected or in which higher costs for contracted workers can be easily compensated by reputational gains.

In the case of SSE, according to their 2014 Annual Report their adoption of the LW entailed that 148 of their 20,000 employees were paid higher wages, roughly costing them an additional $£ 1,000$ per employee. This might be considered a relatively small sum for a FTSE100 corporation, but SSE's commitment to make the LW a requirement for on-site contractors as well as their $2 \mathrm{bn}$ pound supply chain might carry further financial obligations for the company (although it is not known how much exactly this will cost them or they are able to pass costs on to others). In order to legitimize their decision to pay the LW to staff and contractors, SSE lists a range of supporters on their website from local and regional politicians to NGOs, to business champions of CSR and the LW and to unions.

For Penrose Care, financial implications may be more significant as it affects a larger proportion of their staff, particularly in view of the fact that the vast majority of its competitors do not pay LW rates to their care workers. At the same time, because of the recency of the company's formation, it did not have to face any transition costs. Startup companies such as Penrose Care may find it easier to become LW accredited, as they are able to cost for the LW in their budgets from the start.

Companies often use value-based language to explain their decision to become a LW employer, such as 'respect' (Penrose Care), 'fairness' (SSE) and 'responsibility' (Barclays and Friends Life). The decision to pay a LW may arise from a company's ethos, sense of responsibility or (even though this is usually not stated by companies themselves) desire to retain legitimacy. At the same time, they may still find it important to make reference to the business case, to justify to themselves and others that paying a LW makes 'good business sense.' Penrose Care, for example, states on its website that a LW leads to 
'improved morale, lower turnover of staff, reduced absenteeism, increased productivity and improved customer service.' The company's offer of a high quality service, so the managing director states, has enabled them to win contracts despite charging more than their competitors (Allen 2014).

Indeed, effective communication about a company's LW status appears to be crucial for gaining reputational benefits and competitive advantage. Penrose Care posts the Living Wage Employer logo on its homepage for all who visit its website and consider doing business with them to see. Penrose Care has also raised its profile by speaking about their commitment to paying the LW in public meetings and in the media. At the same time, not all LW employers are so upfront regarding their commitment. Often, one needs to search the websites of LW employers very carefully to find any public statement regarding their LW status, or one does not find anything at all. The reluctance on the part of some companies to use their LW accreditation as a marketing tool may be explained by the fact that it may make them vulnerable to criticism, for example, if the LW has not been consistently implemented in the firm or if they have been criticized by the public for certain practices and conduct in other areas of their business.

Finally, LW accreditation may have implications for companies beyond their organizational boundaries, as it may lead them to take up an active role in encouraging other private-sector organizations to follow suit. SSE's Managing Director, for example, expresses his hope that SSE's LW accreditation will also encourage other large companies to do the same. Another example in the UK is KMPG, which aside from being an accredited LW employer itself, operates an extensive research programme on the LW, whose findings use to promote the LW among clients and other privatesector businesses. ${ }^{22}$ In such cases, LW accreditation carries another, symbolic, function, in addition to increasing and maintaining the company's legitimacy.

\section{Conclusion: A Research Agenda}

In this article we have reviewed the important issue of the Living Wage from philosophical, ethical and business perspectives. We have set out the legal, socio-institutional and economic contexts for these perspectives, and have raised salient issues, controversies and unresolved questions, such as the issue of the calculation of the LW and the merits of a voluntary versus a mandatory implementation of the LW. We have also shown that the LW is a reality today and that private-sector businesses are beginning to

\footnotetext{
22 https://www.kpmg.com/UK/en/IssuesAndInsights/ArticlesPublica tions/Pages/living-wage.aspx. Accessed 10 October 2014.
}

implement it into their organizations, although to date we have no systematic understanding of companies' motivations for, and implications of, their active adoption of the LW.

The LW as conceptualized and promoted today in the UK may not meet the idea(l)s of a perfect LW rate, if indeed such a thing exists, and may not be the only way to achieve a fairer and more equal society. Some scholars argue that the LW can at best be seen as having an educational function in a rich, but unequal society (Ciscel 2000) or as a 'rallying cry' to boost the pay for those towards the bottom of the wage league table (Metcalf 2007, cited in Bennett 2014). However, the LW could be considered a pragmatic approach for solving a problem that is not going to go away. It is certainly an idea that is gaining traction and that employers increasingly engage with.

With the LW movement, especially in the UK, we can see a shift occurring away from traditional labour-capital relationships to a civil society led movement, which targets employers in their campaign for decent wages in a highly visible and well-organized manner. Furthermore, the decline of a comprehensive and generous welfare system casts government in a different relationship to both businesses and wider society, and hands them a different remit with regards to ensuring that citizens do not have to live in poverty (Living Wage Commission 2014).

Within this 're-written' social contract and the new nature of relationships between business and (civil) society, business and government, civil society and government, and between businesses, that emerge from this new social contract, a rich research agenda for business ethics, CSR and management scholars can be identified. This research agenda will include questions exploring practical implications as well as questions from a more critical perspective.

What we have aimed to do in our paper is to establish the ground work for key ethical, as well as business, issues that confront organizations thinking of engaging with the LW in a practical, cost-effective way that also makes a meaningful intervention in the lives and welfare of their employees and society at large. In this sense, the tensions already outlined in our paper between the arguments from capability, sustainability and externality open up for exciting avenues for future research.

Beyond the anecdotal, and thus limited, insights provided in the previous section, LW research from an ethics, CSR and management perspective requires systematic investigation of pressing issues such as why might business organizations want to gain accreditation as LW-friendly employers? How do organizations frame these reasons to themselves and to others (shareholders, customers, government, citizens etc.)? What are the reasons for business organizations not to engage with the LW? What are obstacles that keep organizations from adopting the LW? 
What are the differences between different types of business organizations (e.g. different ownership patterns, size, sectors) with regards to these questions (see Pennycook 2012)?

From an organizational perspective, an obvious question to address in greater detail would relate to the impact(s) of adopting the LW upon corporate strategy and the business model for accredited LW employers. These, in turn, are closely associated with companies,' and their managers,' motivations for their signing up to the LW as well as their strategies for managing the inevitable costs associated with paying the LW. Some of these costs would include the overall pay for employees (see Pennycook 2012; Wills and Linneker 2012) and additional costs in time and labour associated with adapting recruitment policies, negotiation with contractors, employee and strategic communications, public relations and so on. How do companies prepare for all these changes? On the positive side of the equation, companies also gain a range of benefits from offering the LW to employees. As mentioned previously, these include reputational benefits, increased morale among employees and increased social capital. Discovering new and potentially unexpected benefits, to employers from offering the LW in their organizations would be an important benefit of further research.

From an international perspective, more research is required into how companies engage with the $\mathrm{LW}$ in relation to their foreign subsidiaries and global supply chains, particularly in developing economies. Currently, LW-accredited companies do not have to roll out the LW in their supply chains. At the same time, there is an expectation that companies that have signed up to the Ethical Trading Initiative Base Code ensure that workers in their supply chains are paid a LW, even though this is considered a complex and difficult undertaking (ETI 2014a, b). An interesting avenue of enquiry would be how LW accreditation may affect companies' perception of, and engagement with, their supply chain responsibilities.

An important avenue for further research also includes the symbolic function LW accreditation will carry for firms, both in relation to their own legitimacy, and in relation to its effect on other companies who are not yet LW employers. Similarly, what are incentives mechanisms and dynamics emerging between employers that may encourage and support the adoption of the LW?

Another area for further research is a more thorough investigation of the effects of the LW on workers. A number of studies have already been done in this area (e.g. Wills and Linneker 2012; Flint et al. 2014), but the capability perspective, looking at the effects for individuals as well as for their families, organizations, communities and the economy, may provide a fruitful lens for further investigations.
Furthermore, it would be fruitful for researchers to investigate how governments and society at large may provide effective incentives and pressure points for companies to adopt the LW. For example, which incentive mechanisms provided by the government may be the most effective drivers for employers to adopt the LW? What role can governments play in brokering productive relationships between LW campaigners and employers? Also, which LW campaign actions will make companies more likely to respond to societal demands to pay a LW? Finally, to what extent are customers willing to reward LW employers with their custom?

These questions suggest that we still have much to understand about how the LW is perceived by employers. Understanding the theoretical and philosophical foundations of the LW as proposed by key thinkers in the field - as our analysis has shown-is a vital step towards developing a research agenda that will satisfy individuals' needs as well as corporate interests and societal objectives towards social equality, fairness and poverty alleviation.

Open Access This article is distributed under the terms of the Creative Commons Attribution License which permits any use, distribution, and reproduction in any medium, provided the original author(s) and the source are credited.

\section{References}

Adams, S., \& Neumark, D. (2005a). The effects of living wage laws: Evidence from failed and derailed living wage campaigns. Journal of Urban Economics, 58, 177-202.

Adams, S., \& Neumark, D. (2005b). Living wage effects: New and improved evidence. Economic Development Quarterly, 19, $80-102$.

Allen, K. (2014). How giving the lowest-paid a big rise could just solve our productivity puzzle. The Guardian, 26 October 2014. Retrieved October 28, 2014, from http://www.theguardian.com/ business/2014/oct/26/lowest-paid-rise-productivity-puzzle-lowwage-growth-uk.

Aquinas, St T. (1947). The summa theologica. New York: Benziger Bros.

Aristotle (1999). Politics. Translated by Benjamin Jowett. Kitchener: Batoche Books.

Arnold, D., \& Bowie, N. (2003). Sweatshops and respect for persons. Business Ethics Quarterly, 13, 221-242.

Arnold, D., \& Bowie, N. (2007). Respect for workers in global supply chains: Advancing the debate over sweatshops. Business Ethics Quarterly, 17, 135-145.

BBC (2013). Ed Miliband pledges living wage tax breaks for firms. BBC News, 3 November 2013. Retrieved July 10, 2014, from http://www.bbc.co.uk/news/uk-24786397.

Bennett, F. (2012). Reflections on the 'living wage'. Soundings, 52, 63-74.

Bennett, F. (2014). The 'living wage', low pay and in work poverty: Rethinking the relationships. Critical Social Policy, 34, 46-65.

Bernstein, J., Brocht, C., \& Spade-Aguilar, M. (2000). How much is enough? Basic family budgets for working families. Washington, DC: Economic Policy Institute. 
Bijl, R. (2011). Never waste a good crisis: Towards social sustainable development. Social Indicators Research, 102, 157-168.

Bowie, N. (1998). A Kantian theory of meaningful work. Journal of Business Ethics, 17, 1083-1092.

Buss, J., \& Romeo, A. (2006). The changing employment situation in some cities with living wage ordinances. Review of Social Economy, 64, 349-367.

Caputo, R. (2008). The unconditional basic income guarantee: Attempts to eclipse the welfare state. International Social Work, 51, 509-518.

Ciscel, D. (2000). The living wage movement: Building a political link from market wages to social institutions. Journal of Economic Issues, 34, 527-535.

Ciscel, D. (2004). The determination in living wages. In D. Figart (Ed.), Living wage movements: Global perspectives (pp. 51-66). London: Routledge.

Clark, K. (2014). Meet the woman behind Ikea's living wage calculator. Marketplace, 5 August 2014. Retrieved October 10, 2014, from http://www.marketplace.org/topics/business/meetwoman-behind-ikeas-living-wage-calculator.

Clary, B. (2009). Smith and living wages: Arguments in support of a mandated living wage. American Journal of Economics and Sociology, 68, 1063-1084.

Davis, A., Hirsch, D., \& Padley, M. (2014). A minimum income standard for the UK in 2014. York: Joseph Roundtree Foundation.

Dower, J., Reidy, T., \& Latimer (2013). Super-rich football clubs attacked for keeping ground staff on poverty wages. The Guardian, 15 December 2013. Retrieved October 10, 2014, from http://www.theguardian.com/society/2013/dec/15/top-foot ball-clubs-attacked-for-low-pay-of-ground-staff.

Eskow, R. (2014). Democrats, meet the minimum-wage movement. The Huffington Post, 5 September 2014. Retrieved October 10, 2014, from http://www.huffingtonpost.com/rj-eskow/democratsmeet-the-minimu_b_5772426.html.

ETI (2013). Living Wage: round-up of key current resources and initiatives. Retrieved October 20, 2014, from http://www.ethicaltrade.org/ resources/key-eti-resources/living-wage-resource-roundup.

ETI (2014a). Our living wage guidance. Retrieved October 20, 2014, from http://www.ethicaltrade.org/sites/default/files/resources/ ETI\%20living\%20wage\%20guidance_0.pdf.

ETI (2014b). ETI's expectations of members regarding the ETI Base Code clause on living wages. Retrieved October 20, 2014, from http://www.ethicaltrade.org/sites/default/files/resources/ETI\% 20Living\%20Wage\%20Expectations_2.pdf.

Figart, D. (2001). Ethical foundations of the contemporary living wage movement. International Journal of Social Economics, 28, 800-814.

Figart, D. (2004). Introduction to living wages around the globe. In D. Figart (Ed.), Living wage movements: Global perspectives (pp. 1-12). London: Routledge.

Fine, J. (2005). Community unions and the revival of the American labour market. Politics and Society, 33, 153-199.

Flint, E., Cummins, S., \& Wills, J. (2014). Investigating the effect of the London living wage on the psychological wellbeing of lowwage service sector employees: A feasibility study. Journal of Public Health, 36, 187-193.

Freeman, R. (2005). Fighting for other folks' wages: The logic and illogic of living wage campaigns. Industrial Relations: A Journal of Economy and Society, 44, 14-31.

Garriga, E. (2014). Beyond stakeholder utility function: Stakeholder capability in the value creation process. Journal of Business Ethics, 120, 489-507.

Grimshaw, D. (2004). Living wage and low pay campaigns in Britain. In D. Figart (Ed.), Living wage movements: Global perspectives (pp. 101-121). London: Routledge.

Groom, B., \& Kuchler, H. (2012). Business chiefs warn over costs of living wage. Financial Times, 5 November. Retrieved July 10,
2014, from http://www.ft.com/cms/s/0/b1df4dc2-2771-11e28c4f-00144feabdc0.html?siteedition=uk\#axzz36yTE3x7H.

Grover, C. (2005). Living wages and the 'making work pay' strategy. Critical Social Policy, 25, 5-27.

Grover, C. (2008). A living wage for London? Benefits, 16, 71-79.

Harcourt, T. (1997). The economics of the living wage. Australian Economic Review, 30, 194-203.

Helm, T. (2013). More than 5 million people in the UK are paid less than the living wage. The Observer, 3 November 2013, p. 8.

Hirsch, D. (2010). Basing a living wage on a minimum income standard. Working Paper. Loughborough: University of Loughborough.

Homecare (2013). London Living Wage Increase Effective Immediately at Penrose Care. 4 November 2013. Retrieved October 20, 2014, from http://www.homecare.co.uk/news/article.cfm/id/ 1561473/london-living-wage-increases-effective-immediatelypenrose-care.

IBE. (2014). Fairness in the workplace: Pay. IBE Briefing 42. London: Institute of Business Ethics.

Jenkins, S. (2007). Thatcher's legacy. Political Studies Review, 5, $161-171$.

Karnes, R. (2009). A change in business ethics: The impact on employer-employee relations. Journal of Business Ethics, 87, 189-197.

Keynes, J. M. (1936). The general theory of employment, interest and money. London: Macmillan.

Lawton, K., \& Pennycook, M. (2013). Beyond the bottom line: The challenges and opportunities of a living wage. London: IPPR \& Resolution Foundation.

Learner, S. (2013). Pressure mounts for better pay for homecare workers. The Guardian, 4 December 2013. Retrieved July 10, 2014, from http://www.theguardian.com/social-care-network/ 2013/dec/04/pressure-mounts-better-pay-homecare-workers.

Living Wage Commission (2014). Work that pays: the final report of the Living Wage Commission.

Low Pay Commission (2014). National minimum wage-Low Pay Commission Report. London.

Luce, S. (2004). Fighting for a living wage. Ithaca, NY: Cornell University Press.

Luce, S. (2005). Lessons from living wage campaigns. Work and Occupation, 32, 423-440.

Markit (2013). Living wage research for KPMG: Structural analysis of hourly wages and current trends in household finances. Henley-on-Thames.

Marx, K. (1977). Capital (Vol. 1). New York: Vintage Books.

McMahon, T. (1985). The contributions of religious traditions to business ethics. Journal of Business Ethics, 4, 341-349.

Metcalf D (2007). Why has the British national minimum wage had little or no impact on employment?' CEP Discussion Paper No. 781. London: Centre for Economic Performance, London School of Economics.

Muilenburg, K., \& Singh, G. (2007). The modern living wage movement. Compensation \& Benefits Review, 39, 21-28.

Mutari, E., \& Figart, D. (2004). Wages and hours-Historical and contemporary linkages. In D. Figart (Ed.), Living wage movements: Global perspectives ( $\mathrm{pp}$. 27-42). London: Routledge.

Nunn, A. (2014). The contested and contingent outcomes of Thatcherism in the UK. Capital \& Class, 38, 303-321.

Onaran, Ö., \& Galanis, G. (2012). Is aggregate demand wage-led or profit-led? National and global effects. Geneva: ILO.

Pennycook, M. (2012). What price a living wage? Understanding the impact of a living wage on firm-level wage bills. London: IPPR $\&$ Resolution Foundation.

Pennycook, M. (2013). A matter of time: the rise of zero-hour contracts. London: Resolution Foundation. 
Perel, M. (2003). An ethical perspective on CEO compensation. Journal of Business Ethics, 48, 381-391.

Pollin, R. (2005). Evaluating living wage laws in the United States: Good intentions and economic reality in conflict? Economic Development Quarterly, 19, 3-24.

Pollin, R., \& Luce, S. (1998). The living wage: Building a fair economy. New York: The New Press.

Preiss, J. (2014). Global labor justice and the limits of economic analysis. Business Ethics Quarterly, 24, 55-83.

Reynolds, D. (2001). Living wage campaigns as social movements: Experiences from nine cities. Labor Studies Journal, 26, 31-65.

Robeyns, I. (2005). Selecting capabilities for quality of life measurement. Social Indicators Research, 74, 191-215.

Ryan, J. (1912). A living wage: Its ethical and economic aspects. London: MacMillan.

Seligman, B. (1968). Permanent poverty: An American syndrome. Chicago: Quadrangle Books.

Sen, A. (1999). Development as freedom. New York: Random House.

Shackleton, L. (2012). Living wage likely to destroy jobs and increase poverty. Institute of Economic Affairs. Retrieved July 10, 2014, from http://www.iea.org.uk/blog/living-wage-likely-to-destroyjobs-and-increase-poverty.

Snarr, C. M. (2011). All you that labor: Religion and ethics in the living wage movement. New York: NYU Press.

Stabile, D. (2008). The living wage: Lessons from the history of economic thought. Cheltenham: Edward Elgar Publishing.

Sweet, P. (2014). Lords urge government to oppose quotas for women. Accountancy Live, 12 September 2014. Retrieved October 20, 2014, from https://www.accountancylive.com/ lords-urge-government-oppose-quotas-women.
Triggle, N. (2013). Elderly 'suffer from poor home care'. BBC News, 13 February 2013. Retrieved July 2014, from http://www.bbc.co. uk/news/health-21430956.

UK Government (2014). The national minimum wage. Retrieved March 18, 2014, from https://www.gov.uk/national-minimumwage/what-is-the-minimum-wage.

van Parijs, P. (1992). Arguing for basic income: Ethical foundations for a radical reform. London and New York: Verso.

Waltman, J. (2004). The case for the living wage. New York: Algora Publishing.

Webb, S., \& Webb B. (1897/1965). Industrial Democracy. New York: Kelly.

Whittaker, M., \& Hurrell, A. (2013). Low pay Britain 2013. London: Resolution Foundation.

Williams, M. (2013). Pay row energy firm gives staff living wage deal. The Herald Scotland, 27 September 2013. Retrieved October 20, 2014, from http://www.heraldscotland.com/news/ home-news/pay-row-energy-firm-gives-staff-living-wage-deal. 22280481.

Wills, J. (2009). The living wage. Soundings, 42, 33-46.

Wills, J., Datta, K., Evans, Y., Herbert, J., May, J., \& McIlwaine, C. (2009). Religion at work: The role of faith-based organizations in the London living wage campaign. Cambridge Journal of Regions, Economy and Society, 2, 443-461.

Wills, J., \& Linneker, B. (2012). The costs and benefits of the London living wage. London: Queen Mary University of London.

World Bank (2013). Gross domestic product 2013. Retrieved October 10, 2014, from http://databank.worldbank.org/data/download/ GDP.pdf. 